\title{
The Relationship Between Abdominal Subcutan Fat Tissue Thickness and HbA1c in Pregnant Women
}

\author{
Aslihan Dilara DEMIR', Pervin KARLI², Durmus AYAN³ \\ Amasya, Turkey
}

\section{ABSTRACT}

OBJECTIVE: Obesity is a very common and important health problem and it has become widespread all over the world. Fat tissue is one of the major endocrine organs. Subcutaneous adipose tissue is associated with many diseases such as coronary artery disease, metabolic syndrome, diabetes, impaired lipid profile. Pregnancy is a special condition with metabolic changes involving all systems. We aimed to investigate the relationship and correlation between abdominal fat and $\mathrm{HbA} 1 \mathrm{c}$ because of the specific metabolic conditions in pregnancy.

STUDY DESIGN: This is a retrospective study. Ninety-nine $(n=99)$ pregnant women between the ages of 20 and 40 were included in the present study. They have not any other chronic diseases. Ultrasonography was performed between 16.-28. weeks. Abdominal subcutaneous fat tissue was measured during 16-28 weeks of pregnancy. Routine biochemical parameters and $\mathrm{HbA} 1 \mathrm{c}$ were evaluated.

RESULTS: Subcutaneous fat tissue had a positive correlation with metabolic parameters such as weight and BMI, and a negative correlation with vitamin $\mathrm{D}$ level. There is a positive strong correlation with $\mathrm{HbA} 1 \mathrm{c}$ level. There was not any correlation between $\mathrm{HbA} 1 \mathrm{c}$ and metabolic parameters like triglyceride, LDL, HDL, and cholesterol.

CONCLUSION: There was a strong positive correlation between abdominal subcutaneous fat tissue thickness and HbA1c. However, we didn't find any correlation between infant weight and metabolic parameters.

Keywords: Abdominal subcutaneous fat tissue, $\mathrm{HbA1c}$, Pregnancy

Gynecol Obstet Reprod Med 2020;26(1):11-16

\section{Introduction}

Obesity is an important metabolic problem because of increasing concern (1). The increase of the fat mass in the subcutaneous tissue and visceral adipose tissue constitute a

\footnotetext{
${ }^{1}$ Amasya University, Sabuncuoğlu Şerefeddin Research Hospital Department of Internal Medicine, Amasya Turkey

${ }^{2}$ Amasya University, Faculty of Medicine, Department of Obstetrics and Gynecology, Amaya Turkey

3 Amasya University, Sabuncuoğlu Serefeddin Research Hospital Department of Biochemistry, Amasya, Turkey

Address of Correspondence: Pervin Karli

Department of Obstetrics and Gynecology,

Amasya University, 05000 Amasya, Turkey parpi2300@hotmail.com

Submitted for Publication: Revised for: Publication 18.05 .2019

08.07.2019

Accepted for Publication:

09.10 .2019

ORCID IDs of the authors:

$A D D$ : 0000-0002-3395-7533, PK:0000-0003-4907-5890 DA: 0000-0003-2615-8474
}

\begin{tabular}{|c|c|}
\hline $\begin{array}{c}\text { Quick Response Code: } \\
\text { a }\end{array}$ & Access this article online \\
\cline { 2 - 2 } & $\begin{array}{l}\text { Website: www.gorm.com.tr } \\
\text { e- mail: info@gorm.com.tr }\end{array}$ \\
\cline { 2 - 2 } & DOI:10.21613/GORM.2019.970 \\
\hline
\end{tabular}

How to cite this article: Demir AD. Karli P. Ayan D. The Relationship Between Abdominal Subcutan Fat Tissue Thickness and HbAlc in Pregnant Women. Gynecol Obstet Reprod Med 2020;26(1):11-16 greater risk for the progression of diabetes, hypertension, and metabolic syndrome than the fat in extremities.

Fat tissue can be considered as a major endocrine organ in the human body. In recent years, many studies have identified cytokines released from adipose tissue. Fukuhara et al. identified an adipokine called visfatin and reported its elevation in patients with diabetes and insulin resistance (2). Again, Viengchareun et al. found that adiponectin decreased insulin resistance (3). Apelin, which is understood to be associated with insulin resistance, were defined by Totemato et al. Fat tissue thickness is important from this point (4).

In a study of Resistance Atherosclerosis (IRAS), researchers have suggested that both subcutaneous fat tissue thickness and visceral fat tissue could bring about metabolic disorders such as insulin resistance (5).

Abdominal fat tissue acts as an endocrine organ, releasing a variety of cytokines causing an impairment of the metabolic status. Therefore, abdominal and visceral fat, as indicated in the study of Framingham Heart, leads to deterioration in metabolic parameters such as hypertension, serum lipid levels, fasting blood glucose, insulin resistance. visceral fat is more effective than subcutaneous abdominal fat tissue growth in the emergence of this situation $(6,7,8)$. Previous studies have 
shown that body fat tissue, especially abdominal subcutaneous fat, causes many disorders such as coronary artery disease, diabetes, and high cholesterol levels. It was emphasized that local fat accumulation, especially abdominal fat, was very effective compared to the total body fat (10-12).

The molecules related to glucose metabolism and development of gestational diabetes such as leptin, adiponectin, resistin are released from maternal subcutaneous adipose tissue and many fetal tissues $(13,14)$. In the early stages of pregnancy, there is an increase in lipoprotein lipase activity in adipose tissue and extrahepatic lipoprotein lipase activity. Therefore, there is an increase in fat deposition in the first months while the catabolism of these fat depots in later periods. The increase in fat depots causes the increase of proinflammatory cytokines and insulin resistance and the tendency to diabetes (15). Increased lipoprotein lipase activity boosts the intake of free fatty acids into adipose tissue and esterification of triglycerides (16), which explains the increase in pregnant fat tissues.

We aimed to investigate whether the tendency of diabetes caused by pregnancy has a correlation with HbA1c between the $16^{\text {th }}$ and $28^{\text {th }}$ gestation weeks of pregnant women who were not diagnosed with diabetes. Accordingly, the relationship between subcutaneous fat tissue thickness and HbAlc in pregnant women was examined.

\section{Material and Method}

Our study was approved by Tokat Gaziosmanpasa Uni. Medical Faculty in the date of 03.07.2018 and no 18-KAEK121. All authors and the study protocol have complied with the World Medical Association Declaration of Helsinki regarding the ethical conduct of research involving human subjects

The study included patients who were consulted to the obstetrics and gynecology clinics for routine examinations, who are between 20 and 40 years of age, and between 16-28 weeks of gestation, had no additional chronic disease in their followup and had no history of diabetes before and during pregnancy. We compared the subcutaneous fat tissue thickness and HbA1c. These patients were retrospectively examined. $\mathrm{HbAlc}$ and other routine examinations were planned to be accessed through the hospital database. Patients were between 16 - 28 weeks. Because of their routine USG program. We obtained their routine examination test results from Amasya University Sabuncuoğlu Şerefeddin Education and Research Hospital database. In this study, Ultrasound results of patients who were between the 16 and $28^{\text {th }}$ weeks and had normal values of the liver functions, kidney functions, free- triiodothyronine (ft3), free-thyroxine (fT4), thyroid-stimulating hormone (TSH), white blood cell (WBC), hemoglobin (Hb), hematocrit (HCT), platelets (PLT), and C-reactive protein (CRP) were included. Their measurements of maternal subcutaneous adipose ultrasound thickness in between the 16 . and 28 . weeks and $\mathrm{HbA} 1 \mathrm{c}$ was compared. The ultrasonographic examinations were made by single-same gynecologists using a Mindray DP-5 (B\&W Ultrasound System) ultrasound machine with a $3.75 \mathrm{MHz}$ convex probe.

Blood lymphocyte measurements (normal value: 20-40\%) were performed on the MindRay 6.800 in hemogram device. Subcutaneous fat tissue thickness measurement was evaluated using the c5-2 convex probe of mindray DC-7 in harmonic imaging mode and at $3.8 \mathrm{MHz}$ frequency set. HbA1c measurements (normal value: $4.0-6.0 \%$ ) were measured in the Premier HB9210 device (TrinityBiotechPlc. Bray, Co.Wicklow, Ireland). Hormone normal value: (fT4: 12-22 pmol/1, 0.93-1.7 ng/dl,), (fT3: 3.1-6,pmol/L, 2.0-4.4 pg/mL). They were measured in Cobas 801 (Roche Diagnostics, U.S.A.) device, and the biochemical parameters were measured in the Beckan Coulter AU5800 (BeckanCoulter, Inc.Canada) device.

\section{Statistical Analysis:}

Statistical analysis was performed using SPSS 15.0 for Windows. The normal distribution, Skewness, Kurtosis values were determined with Kolmogorov-Smirnov (Lilliefor significance correction), Shapiro-Wilk tests and histogram graphics. The paired-sample $t$-test was used for parameters that provide a normal distribution for numerical variables. $P<0.05$ was determined as statistically significant. Pearson correlation analysis was performed when parametric test conditions were provided, and Spearman correlation analysis was performed when parametric test conditions were not provided.

\section{Results}

Descriptive statistics were given as number and percent for categorical variables and mean, standard deviation, minimum, maximum, median for numeric variables (Table I, II).

The mean age of the patients was 27.6 years. The mean BMI was 26.67 (Table I). There was not menstrual irregularity, polycystic ovarian syndrome (PCOS), and not smoking history in patients. More than half were at the $24^{\text {th }}-30^{\text {th }}$ gestational week. $47.5 \%$ of patients were at earlier gestational week (Table II). The majority of the patients included in the study were a housewife. (75.8\%) (Table III).

According to the results of the correlation among the parameters; there was a strong positive correlation among BMI, weight and subcutaneous fat tissue thickness. However, vitamin D showed a negative correlation.

There was a positive significant correlation between abdominal subcutaneous fat tissue thickness and HbAlc. There was a weak positive correlation between the subcutaneous thickness and the fT4 hormone. Since the distribution of the tests did not provide the normal distribution conditions, Spearman correlation analysis was performed.

According to the results of the correlation analysis among the parameters; 
Table I: Age, weight and BMI values

\begin{tabular}{lcccc}
\hline Descriptive Statistics $(n=99)$ & Minimum & Maximum & Mean & SD $( \pm)$ \\
\hline Age $($ Year) & 18 & 38 & 27.6 & 4.78 \\
BMI $\left(\mathrm{Kg} / \mathrm{m}^{2}\right)$ & 16.53 & 42.85 & 26.67 & 5.19 \\
Weight $(\mathrm{kg})$ & 44 & 111 & 69.09 & 13.01 \\
\hline
\end{tabular}

SD: Standart deviation, BMI: Body mass index

Table II: Some characteristics of the patients

\begin{tabular}{|c|c|c|c|c|c|c|c|c|c|c|c|}
\hline \multicolumn{2}{|c|}{$\begin{array}{c}\text { Menstrual } \\
\text { irregularity }(n=99)\end{array}$} & \multicolumn{2}{|c|}{$\begin{array}{l}\text { Pubescence } \\
(n=99)\end{array}$} & \multicolumn{2}{|c|}{$\begin{array}{l}\text { PCOS } \\
(n=99)\end{array}$} & \multicolumn{2}{|c|}{$\begin{array}{l}\text { D vit. Use } \\
\qquad(n=99)\end{array}$} & \multicolumn{2}{|c|}{$\begin{array}{l}\text { Gestational Week } \\
\qquad(n=99)\end{array}$} & \multicolumn{2}{|c|}{$\begin{array}{l}\text { Smoking } \\
(n=99)\end{array}$} \\
\hline yes & no & yes & no & yes & no & yes & no & $16-20$ & $24-30$ & yes & no \\
\hline$\% 8.1$ & $\% 91.9$ & $\% 11.1$ & \%88.9 & $\% 8.1$ & $\% 91.9$ & $\% 33.3$ & \%67.7 & $\% 47.5$ & $\% 52.5$ & $\% 2$ & $\% 98$ \\
\hline$n=8$ & $\mathrm{n}=91$ & $\mathrm{n}=11$ & $n=8$ & $n=8$ & $n=91$ & $n=33$ & $n=66$ & $n=47$ & $n=52$ & $n=2$ & $n=97$ \\
\hline
\end{tabular}

Table III: Professional distribution

\begin{tabular}{cccccc}
\hline Housewife & Teacher & Health worker & Company employee & Artisan & Other \\
\hline$\% 75.8(n=75)$ & $\% 7.1(n=7)$ & $\% 6.1(n=6)$ & $\% 2(n=2)$ & $\% 2(n=2)$ & $\% 7.1(n=7)$ \\
\hline
\end{tabular}

There was a strong positive correlation between body mass index (BMI) and weight $(r=0.910, p<0.001)$. A strong positive correlation $(r=0,534, p<0.001)$ was present between BMI and subcutaneous thickness. A weak negative correlation between BMI and vitamin D $(r=-0.204, p=0.043)$ was found. A positive correlation was found between weight and subcutaneous thickness of patients $(r=0.581, p<0.001)$. There was a strong negative correlation $(r=-0.303, p=0.002)$ between the weight gain and the fT4 hormone $(r=-0.303, p=0.002)$. A weak correlation between subcutaneous thickness and fT4 hormone ( $r=0.238, p=0.019)$ was determined, there was no significant correlation between the other parameters $(p>0.05)$ (Table IV).

There was a strong positive correlation between $\mathrm{HbA} 1 \mathrm{c}$ and subcutaneous thickness $(r=0.414, p<0.001)$ (Figure 1$)$. There was no significant correlation between $\mathrm{HbA} 1 \mathrm{c}$ and other parameters $(p>0.05)$ (Table V). In addition, when the subcutaneous thickness was taken as normal $15 \mathrm{~mm}$, we found that the values of the patients were significantly higher than the normal values $(p<0.001)$. According to the correlation result, HbA1c was significantly correlated with subcutaneous adipose tissue thickness $(p<0.01, r: 0,414)$.

Infant sex ( $n=61): 32(52.5 \%)$ were female, 29 (47.5\%) were male.

There was no correlation between subcutaneous thickness and infant weight ( $r=0.011, p=0.931)$. There was no correlation between infant weight and triglycerides $(r=-0.018$, $p=0.892$,). And furthermore, there was no correlation between infant weight and cholesterol $(r=0.061, p=0.643$,). We didn't find any correlation between infant weight and LDL ( $r=0.041, p=0.753$ ). There was no correlation between infant weight and HDL $(r=0.088, p=0.500)$. There was no correlation between HbAlc and triglyceride $(r=0.039, p=0.763)$. No correlation was found between $\mathrm{HbA} 1 \mathrm{c}$ and cholesterol $(r=$ $0.059, p=0.649)$. No correlation was found between HbA1c and LDL $(r=0.024, p=0.855)$. There was no correlation between HbA1c and HDL $(r=-0.051, p=0.696)$ (Table V).

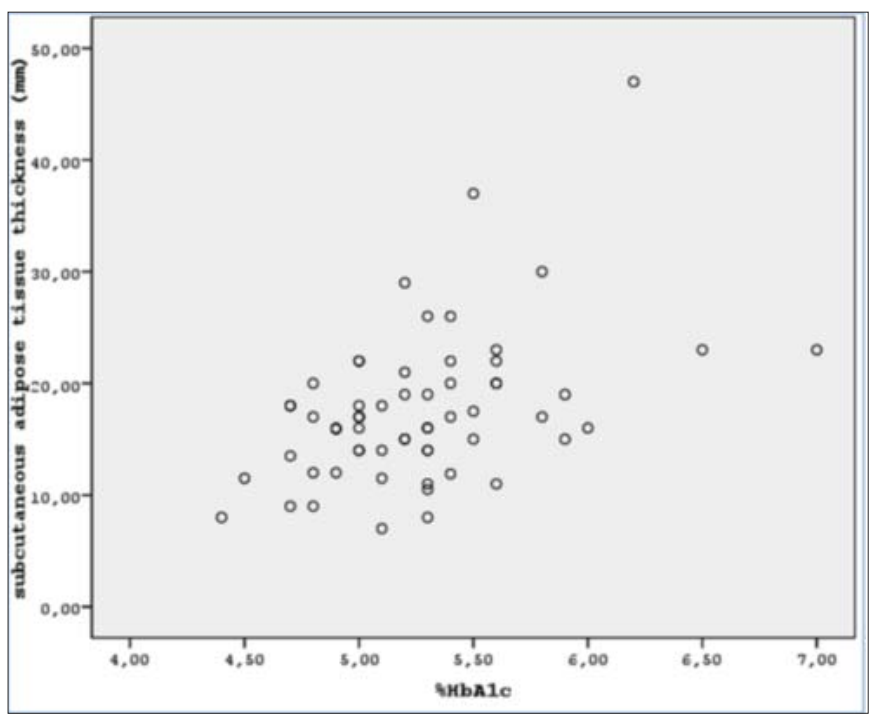

Figure 1: Correlation with subcutaneous adipose tissue thickness and HBA1C 
Table IV: Number, mean and standard deviation values of biochemical variables

\begin{tabular}{|c|c|c|c|c|}
\hline$n=99$ & Minimum & Maximum & Mean & S.D. $( \pm)$ \\
\hline Weight gained $(\mathrm{kg})$ & 1 & 20 & 5.65 & 3.95 \\
\hline Glucose (mg/dL) & 60 & 146 & 85.45 & 12.80 \\
\hline Triglycerides (mg/dL) & 65 & 407 & 163.3 & 63.72 \\
\hline Cholesterol (mg/dL) & 115 & 301 & 221.93 & 38.04 \\
\hline LDL (mg/dL) & 39 & 886 & 156.38 & 81.72 \\
\hline AST (U/L) & 9 & 85 & 18.77 & 8.38 \\
\hline ALT (U/L) & 4 & 71 & 14.46 & 10.30 \\
\hline $\mathrm{HDL}(\mathrm{mg} / \mathrm{dL})$ & 14 & 110 & 63.73 & 16.76 \\
\hline Subcutaneous thickness ( $\mathrm{mm})$ & 7 & 49 & 18.49 & 7.31 \\
\hline $\mathrm{fT} 3 \mathrm{pg} / \mathrm{mL}$ & 1.02 & 53 & 3.30 & 5.06 \\
\hline fT4 ng/dL & 0.63 & 2.85 & 1.06 & 0.30 \\
\hline TSH ulU/mL & 0.03 & 6.08 & 1.96 & 1.04 \\
\hline $\mathrm{D}$ vit ng/dL & 2.78 & 66.70 & 10.52 & 8.29 \\
\hline $\mathrm{HbA1c} \%$ & 4.40 & 7.80 & 5.27 & 0.48 \\
\hline
\end{tabular}

Table V: Lipid profile of the patients

\begin{tabular}{lcccccccc}
\hline Pregnant lipid profile & \multicolumn{2}{c}{ Triglycerides } & $(\mathrm{mg} / \mathrm{dL})$ & \multicolumn{2}{c}{ Cholesterol $(\mathrm{mg} / \mathrm{dL})$} & \multicolumn{2}{c}{$\mathrm{LDL}(\mathrm{mg} / \mathrm{dL})$} & \multicolumn{2}{c}{$\mathrm{HDL}(\mathrm{mg} / \mathrm{dL})$} \\
\hline & $r$ & $p$ & $r$ & $p$ & $r$ & $p$ & $r$ & $p$ \\
\hline Infant weight $(\mathrm{g})$ & -0.018 & 0.931 & 0.061 & 0.643 & 0.041 & 0.753 & 0.088 & 0.5 \\
Pregnancy HbA1c $(\%)$ & 0.039 & 0.763 & 0.059 & 0.649 & 0.024 & 0.855 & -0.051 & 0.696 \\
\hline
\end{tabular}

\section{Discussion}

Park et al. have investigated the effect of body fat tissue compartments on insulin efficacy, sensitivity, and resistance in healthy individuals. They have reported that the abdominal fat tissue was more dominant than the subcutaneous tissue on insulin sensitivity is negatively affected in individuals with visceral fat. In another study, Marin et al. have achieved similar results. They have reported that visceral intra-abdominal fat tissue is effective in insulin sensitivity even in individuals with normal blood glucose levels (17).

The apparent effect of obesity on diabetes and insulin resistance is known de Mutsert, et al. have investigated the impact of body fat compartments and the tissue of subcutaneous and visceral fat on the development of insulin resistance and diabetes. They have reported that either fatty tissue compartments in males are effective in the development of insulin resistance. They have stated that some visceral tissue was in the foreground in women (18).

Köşüş, et al. $\mathrm{f}$ have found that maternal subcutaneous fat tissue thickness was associated with HBA1C and CRP-related inflammation indicators in pregnant women between the weeks of 24-28. As the thickness of the fat tissue increases, they have found the increase of these values proportionally (19).

Suresh, et al. have studied with 1200 pregnant women between the $18^{\text {th }}$ and $22^{\text {nd }}$ gestational weeks and compared sub- cutaneous fat tissue and BMI in terms of obesity-related pregnancy complications. They have found that the subcutaneous fatty tissue was useful in terms of obesity and its complications, as well as an easy-to-apply measurement (20).

Kennedy, et al. have conducted a study of 1510 patients for two years. They have measured the thickness of subcutaneous fat between 11-14 and 18-22 weeks. They have found a significant increase in abdominal subcutaneous fat tissue in the development of metabolic disorders such as diabetes, hypertension, especially they have found that the thickness increase in weeks 18-22 was predictive. In addition, Complications of pregnancy have been reported to increase in these patients (21).

Bruno, et al. have studied 139 pregnant women who were between 9 and 12 in gestational weeks. They have reported that weight gain and subcutaneous fat tissue increased in pregnancy were related to negative metabolic results, the development of diabetes and LGA (large gestational age) for infants (22). Consequently, all studies have shown that the inflammatory environment caused by increased abdominal subcutaneous fat tissue and increased weight gain during pregnancy facilitates the risk of diabetes, hypertension, cholesterol, coronary artery disease, and brings complications such as LGA infant, cesarean delivery, macrosomia.

In the present study, BMI increase in patients resulted in increased weight gain and subcutaneous fat tissue thickness, 
and there was a negative correlation with vitamin D. We determined the strong positive correlation between abdominal fat tissue thickness and HbAlc. There was no relationship between abdominal subcutaneous thickness, lipid profile and infant weight. The mean BMI of our patients was 26.67. As the thickness of the subcutaneous fat tissue is more variable and lower in obese women compared to normal women due to the increasing gestational week. Just like all many studies, abdominal fat tissue thickness is correlated with $\mathrm{HbA} 1 \mathrm{c}$. Abdominal fat tissue thickness gives us clues about how the patients are close to diabetes and metabolic disorders. It is important to gain weight control for preventing such metabolic situations (23).

We were lack of information about the diet status, the daily calorie intake, physical activities of the individuals who participated in the study and whether they had a sedentary life or not (most of the patients were housewives, there were also some employees. More beneficial results can be obtained in a further study covering obesity patients. Studies that will be done with more patients are important to shed light on the research subject in later times.

Acknowledgments: We have no financial support. Author contribution: ADD: Constructing an idea or hypothesis for the research, designing and/or planning methodology, Literature review, writer, supervision and critical review. $P K$ : Designing and/or planning methodology, providing material and environmental supports data collection, literature review, writer, supervision and critical review. DA: Analysis and/or interpretation, supervision and critical review, designing and/or planning methodology,

conflict of interest: Authors have declared that they have no conflict of interest

Funding: We didn't receive funding from any institution

\section{References}

1. Onat A. Türkiye'de Obezitenin Kardiyovasküler Hastal1klara Etkisi. Turk Kardiyol Dern Ars. 2003;31(5):27989.

2. Fukuhara A, Matsuda M, Nishizawa M, Segawa K, Tanaka M, Kishimoto K et al. Visfatin a protein secreted by visceral fat that mimics the effects of insulin. Science 2005;307(5708): 426-30.

3. Viengchareun S, Zennaro MC, Pascual-Le Tallec L, Lombes M. Brown adipocytes are novel sites of expression and regulation of adiponectin and resistin. FEBS Lett. 2002;532(3):345-50.

4. Hosoya M, Kawamata Y, Fukusumi S, Fujii R, Habata Y, Hinuma $\mathrm{S}$ et al. Molecular and functional characteristics of APJ. Tissue distribution of mRNA and interaction with the endogenous ligand apelin. J Biol Chem. 2000;275 (28):21061-7.

5. Wagenknecht LE, Langefeld CD, Scherzinger AL, Norris
JM, Haffner SM, Saad MF et al. Insulin sensitivity, insulin secretion, and abdominal fat: the Insulin Resistance Atherosclerosis Study (IRAS) Family Study. Diabetes. 2003;52(10):2490-6.

6. Saijo Y, Kiyota N, Kawasaki Y, Miyazaki Y, Kashimura J, Fukuda $\mathrm{M}$ et al. Relationship between C-reactive protein and visceral adipose tissue in healthy Japanese subjects. Diabetes Obes Metab. 2004;6(4):249-58.

7. Kanaya AM, Harris T, Goodpaster BH, Tylavsky F, Cummings SR. Health, Aging, and Body Composition (ABC) Study. Adipocytokines attenuate the association between visceral adiposity and diabetes in older adults. Diabetes Care. 2004;27(6):1375-80.

8. Azuma K, Katsukawa F, Oguchi S, Murata M, Yamazaki $\mathrm{H}$, Shimada A et al. Correlation between serum resistin level and adiposity in obese individuals. Obes Res. 2003;11(8):997-1001.

9. Miyazawa-Hoshimoto S, Takahashi K, Bujo $H$, Hashimoto N, Saito Y. Elevated serum vascular endothelial growth factor is associated with visceral fat accumulation in human obese subjects. Diabetologia. 2003;46 (11): 1483-8.

10. Ohlson LO, Larsson B, Svärdsudd K, Welin L, Eriksson $\mathrm{H}$, Wilhelmsen L, et al. The influence of body fat distribution on the incidence of diabetes mellitus. 13.5 years of follow-up of the participants in the study of men born in 1913. Diabetes. 1985;34(10):1055-8.

11. Lapidus L, Bengtsson C, Larsson B, Pennert K, Rybo E, Sjöström L. Distribution of adipose tissue and risk of cardiovascular disease and death: a 12 year follow up of participants in the population study of women in Gothenburg, Sweden. Br Med J (Clin Res Ed). 1984;289(6454):125761 .

12. Ducimetiere P, Richard J, Cambien F. The pattern of subcutaneous fat distribution in middle-aged men and the risk of coronary heart disease: the Paris Prospective Study. Int J Obes. 1986;10(3):229-40.

13. Weyer C, Funahashi T, Tanaka S, Hotta K, Matsuzawa Y, Pratley RE et al. Hypoadiponectinemia in obesity and type 2 diabetes: close association with insulin resistance and hyperinsulinemia. J Clin Endocrinol Metab. 2001;86(5): 1930-5.

14. Steppan CM, Bailey ST, Bhat S, Brown EJ, Banerjee RR, Wright CM. The hormone resistin links obesity to diabetes. Nature. 2001;18;409(6818):307-12.

15. Herrera E, Lasunción MA, Palacín M, Zorzano A, Bonet B. Intermediary metabolism in pregnancy. First theme of the Freinkel era. Diabetes. 1991;40 (Suppl 2):83-8.

16. Knopp RH, Herrera E, Freinkel N. Carbohydrate metabolism in pregnancy. 8. Metabolism of adipose tissue isolated from fed and fasted pregnant rats during late gestation. J Clin Invest. 1970;49(7):1438-46.

17. Mårin P, Andersson B, Ottosson M, Olbe L, Chowdhury 
B, Kvist H. The morphology and metabolism of intraabdominal adipose tissue in men. Metabolism. 1992;41 (11): 1242-8.

18. de Mutsert R, Gast K, Widya R, de Koning E, Jazet I, Lamb H. Associations of Abdominal Subcutaneous and Visceral Fat with Insulin Resistance and Secretion Differ Between Men and Women: The Netherlands Epidemiology of Obesity Study. Metab Syndr Relat Disord. 2018;16 (1):54-63.

19. Köşüş N, Köşüş A, Turhan N. Relation between abdominal subcutaneous fat tissue thickness and inflammatory markers during pregnancy. Arch Med Sci. 2014;10(4): $739-45$.

20. Suresh A, Liu A, Poulton A, Quinton A, Amer Z, Mongelli $\mathrm{M}$, et al. Comparison of maternal abdominal subcutaneous fat thickness and body mass index as markers for pregnancy outcomes: A stratified cohort study. Aust N Z J Obstet Gynaecol. 2012;52(5):420-6.

21. Kennedy NJ, Peek MJ, Quinton AE, Lanzarone V, Martin A, Benzie R, et al. Maternal abdominal subcutaneous fat thickness as a predictor for adverse pregnancy outcome: a longitudinal cohort study. BJOG. 2016;123(2):225-32.

22. Pianeta Nutrizione kids: international pediatric conference on food, physical activity, growth and well-being: Milan, Italy. 25-27 June 2015. Ital J Pediatr. 2016;42 (Suppl 1): 53. (No authors listed).

23. Bruno R, Petrella E, Bertarini V, Neri I, Facchinetti F. Lifestyle-induced maternal body composition changes and birthweight in overweight/obese pregnant women. J Pediatr Neonat Individual Med. 2015;4(2):e040227. 